\title{
Reconfiguring the traditional knowledge system for providing earthquake resistance: The case of post-disaster reconstruction of Khokana Village, Nepal
}

\author{
Reconfigurar el sistema de conocimientos tradicionales para \\ resistir a los terremotos: El caso de la reconstrucción del pueblo \\ de Khokana, en Nepal, tras sufrir este desastre natural \\ Reconfigurando o sistema de conhecimento tradicional para a \\ criação de resistência a terramotos: $O$ caso de reconstrução pós- \\ catástrofe da aldeia de Khokana, Nepal
}

Keywords $\mid$ Palabras clave $\mid$ Palaviras chave

Cultural landscapes, Local communities, Spatial configuration, Collective memory, Community resilience

Paisajes culturales, Comunidades locales, Configuración espacial, Memoria colectiva, Adaptabilidad comunitaria

Paisagens culturais, Comunidades locais, Configuração espacial, Memória colectiva, Resiliência comunitária

\begin{abstract}
Resumen | Resumo
Cultural landscapes represent a closely woven net of inter-relationships between people, events and places over time; they are a symbol of the growing recognition of the fundamental links between local communities and their heritage, between people and their natural environment, and are hence crucial to their identity. In architectural projects like post-disaster reconstruction, which revolves around the needs of the communities decimated by a disaster, decisions taken become especially critical, as they have a long-term impact on the community and its built environment. It therefore requires one to take into account the cultural, social, and environmental context. This paper considers the case of Khokana, a traditional Newari settlement in the Kathmandu valley, in order to study its spatial configuration, determined by its socio-cultural activities, through the lens of collective memory mapping. It further analyzes the repercussions on the intangible values and tangible built environment of the community following the $2015 \mathrm{Nepal}$ earthquake, and proposes a new design approach based on an understanding of Khokana's traditional knowledge system and practices. Finally, we propose a model to achieve community resilience while keeping the community's values and spatial ethos intact.
\end{abstract}

Los paisajes culturales representan una red de relaciones estrechas entre personas, acontecimientos y lugares a lo largo del tiempo: son un símbolo del reconocimiento creciente de los vínculos fundamentales entre las comunidades locales y su patrimonio, entre las personas y el entorno natural y, por consiguiente, cruciales para su identidad. En proyectos arquitectónicos como los de reconstrucción tras una catástrofe, que giran en torno a las necesidades de comunidades diezmadas por un desastre, las decisiones adoptadas se vuelven especialmente críticas, ya que tienen un impacto a largo plazo en la comunidad y su entorno construido. Por consiguiente, hay que tener en cuenta el contexto cultural, social y medioambiental. Este artículo analiza el caso de Khokana, un asentamiento newari tradicional en el valle de Katmandú, 
para estudiar su configuración espacial, determinada por sus actividades socioculturales, a través de la perspectiva de la memoria colectiva. Por otra parte, se analizan las repercusiones que tuvo el terremoto de Nepal de 2015 en los valores inmateriales y el entorno construido de la comunidad; asimismo se propone la reconfiguración de los proyectos mediante la comprensión del sistema de conocimientos y las prácticas tradicionales de Khokana. En la última parte se propone un modelo para conseguir una mayor adaptabilidad comunitaria manteniendo intactos sus valores y ética del espacio.

As paisagens culturais representam uma rede intimamente tecida de inter-relações entre pessoas, acontecimentos e lugares ao longo do tempo; são um símbolo do crescente reconhecimento dos laços fundamentais entre as comunidades locais e o seu património, entre as pessoas e o seu ambiente natural, e são por isso cruciais para a sua identidade. Em projectos arquitectónicos como as reconstruções pós-catástrofe, que giram em torno das necessidades das comunidades dizimadas por uma catástrofe, as decisões tomadas tornam-se especialmente decisivas, uma vez que têm um impacto a longo prazo na comunidade e no seu ambiente construído. Por conseguinte, é necessário ter em conta o contexto cultural, social, e ambiental. O presente artigo parte do caso de Khokana, uma povoação tradicional Newari no vale de Catmandu, de forma a estudar a sua configuração espacial, determinada pelas suas actividades socioculturais, através da perspectiva do mapeamento da memória colectiva. Analisa ainda as repercussões na comunidade em termos dos seus valores intangíveis e ambiente construído tangível devido ao impacto do terramoto de 2015 no Nepal; propondo assim reconfigurações de desenho através da compreensão do sistema de conhecimento e práticas tradicionais de Khokana. Esta última etapa procura propor um modelo para alcançar a resiliência da comunidade, mantendo intactos os valores e o ethos espacial da comunidade.

\section{Introduction}

An earthquake of magnitude Mw 7.8 struck Nepal on April 25 $5^{\text {th }}, 2015$, with its epicenter located 77 kilometres north-west in the Kathmandu Valley. It affected the lives of almost eight million people, which is about one-third of the country's population. The catastrophic earthquake was followed by more than 300 aftershocks of Mw 4.0 and higher (National Planning Commission of Nepal 2015: B). The repercussion of the event was widespread, damaging about half a million private and public buildings as well as other infrastructure. A range of government schemes and policies to combat the impact and boost a rehabilitation plan was introduced as a result. These included providing cash grants for the reconstruction of private buildings and action plans and guidelines for ensuring cost-effective and earthquake-resistant structures. However, most of the reconstruction approaches endorse centrally driven strategies rather than opting for place-based development, and for this reason the results usually lack aspects like "place identity", "socio-cultural values" and a "sense of place", and are hence unable to effectively address local development issues. Reconstruction should be considered an opportunity to enhance communities by encouraging design decisions that better reflect local realities and contextual conditions, rather than promoting a top-down initiative (UNESCO 2014) (Fig. 1).

According to UNISDR, reconstruction is defined as "sustainable restoration of resilient infrastructure, services, housing, and livelihoods required for the full functioning of a community affected by the disaster while improving the economical, physical, social, cultural, and environmental assets" (UNISDR 2017).

The Riga Charter states that reconstruction is considered "a replication of cultural heritage"; in other words, "as a rule of distortion of proof of the past where each design work ought to mirror the hour of its own creation, in the conviction that thoughtful new structures can maintain the ecological setting" (ICCROM 2000). Nevertheless, an examination of the facts demonstrates that reconstruction should not be ruled out a priori, but rather be considered on a case-by-case basis. Especially in those instances where the intangible and tangible heritage of a place continue to sustain the local building culture (traditional knowledge, craftsmanship, and technique), restoration is totally feasible and even necessary to preserve local cultural heritage. The character-defining element that "reflects" the sense of place, is not affected by the "time of creation" (Khalaf 2017: 233). Ruskin stated that "the greatest glory of a building is not in its stones, nor in its gold. Its glory is in its Age, and in that deep sense of voicefulness, of stern watching, of mysterious sympathy, nay, even of approval or condemnation, which we feel in walls that have long been washed by the passing waves of humanity" (Ruskin 1849); but what is most valuable is not the "golden strain of time", but rather the intangible system associated with conservation practices over time.

A place-based approach, at the heart of a people-centered strategy, restores livelihoods and socio-economic structures, and thereby critically ensures a "sense of place" as its core element that reflects the community's identity, 


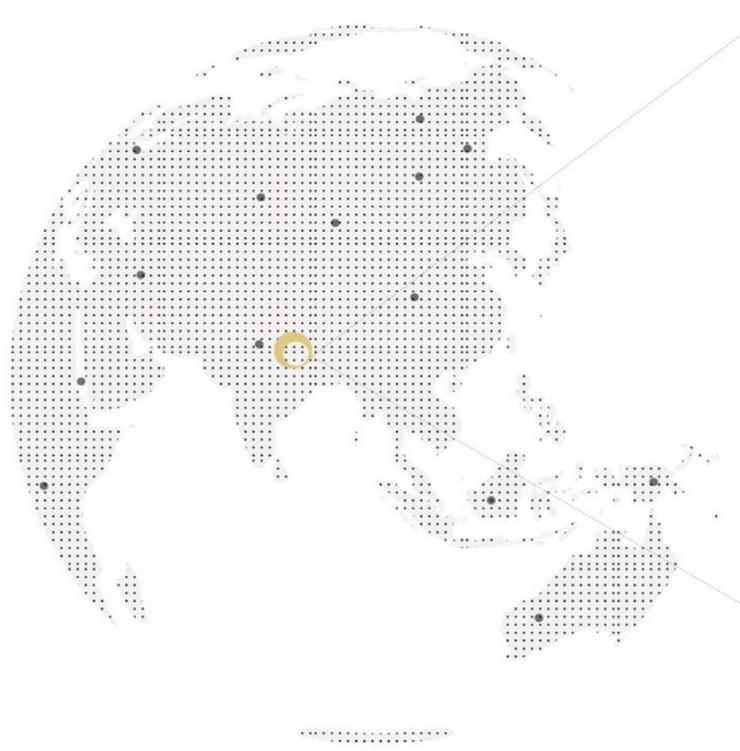

Figure 1.2015 Nepal earthquake and affected areas

values, culture, and traditions. At the same time, places may acquire new values and meanings due to a post-disaster crisis and socio-economic changes, and this evolution in terms of spaces, architecture, and materiality must be accepted and reflected in the reconstruction process. This paper attempts to integrate the same philosophy to propose a new approach to design for the post-disaster reconstruction of Khokana village, while keeping the community's traditional values and spatial ethos intact by understanding the intangible and the tangible aspects of their cultural heritage This paper further analyzes the impact of the 2015 Nepal earthquake on the community, through a detailed damage assessment of its buildings and infrastructures while appreciating the role of architecture in restoring the community and in identifying areas to be preserved and worked on.

The research essentially focuses on reconstruction planning and is limited to the study of Khokana's physical, geographical, and socio-cultural and built environment for understanding of the needs, values, work-life patterns, spaces, traditional knowledge systems, and architectural vocabulary of the community. The data collected through primary and secondary studies are based on the authors' understanding of the community and might not be completely accurate in some cases. Furthermore, the following research is limited to the impact-study of the 2015 Nepal earthquake on the historical settlement of Khokana and does not include any buildings outside the core area.
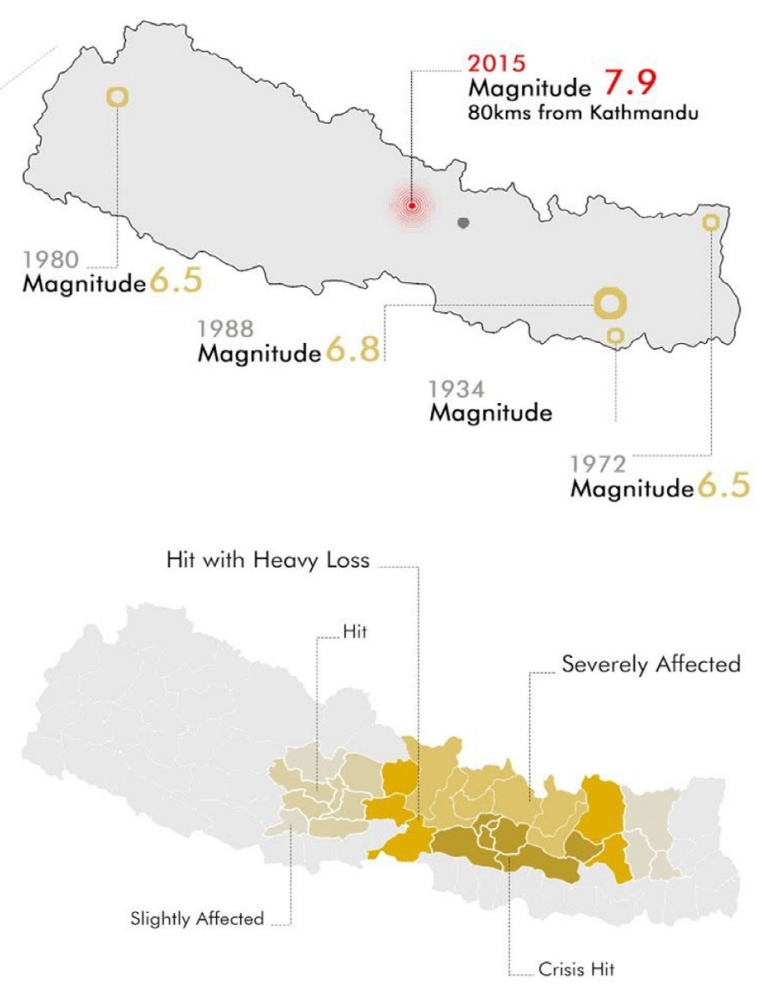

\section{Research methodology}

The research methodology follows a descriptive research approach where both primary and secondary data are collected for a better understanding of the community. This qualitative method was considered the most appropriate strategy to properly understand the place and its community as a basis for the proposed reconstruction strategy. The method caters to the "what", "why" and "how" aspects rather than focusing on numerical data. It tries to capture real-life scenarios.

The primary data were collected from home-owners, local organizations and the municipality with the help of questionnaires (open-ended questions), live-interviews, photographs and architectural surveys, whereas the secondary data were extracted from books, newspaper articles, magazines, journals, and various related websites dealing directly or indirectly with the topic.

\section{Design strategy: A place-based approach for sustainable reconstruction}

A sustainable reconstruction framework requires a connection between the physical context of a given territory and the intangible values (historic, cultural, and social) that form the identity of that place (Clemente and Salvati 2017). Hence, while assessing architectural approaches in a post-disaster context, it becomes imperative to identify the unique needs of each community and explore design solutions that respect the significance and integrity of its 
cultural resources and can also produce a coherent whole once rehabilitation has been completed.

A post-disaster reconstruction involves more than the rebuilding of damaged and destroyed structures. It is an opportunity to create new urban forms, develop economic opportunities, and enhance the quality of life to build back a stronger community (United Nations 2008). As this research aims to propose a place-based reconstruction plan for the "lived-in" heritage settlement of the Khokana community, a deeply rooted understanding of the needs of the inhabitants and the place is necessary.

A place-based approach helps to develop an understanding of the local context, drawing on a broad range of evidence and local experience and research on the traditional knowledge system. It includes efforts to build neighborhood cohesion and to improve facilities, the built environment and economic opportunities in a region.

\section{Place and place attachment}

A space can be conceived of as abstract geometries (distance, direction, size, shape, volume) detached from cultural interpretation (Gieryn 2000), but it is when individuals or groups imbue the space with meaning that spaces are transformed into places. According to Edward Relph, places are essentially "centers of meaning, constructed out of lived experience" that over time are perceived as significant to the lives of the people (Relph 1976). Their unique physical, historical, cultural, and social characteristics can hence support or deter communities from achieving their vision for a better life. The concept of place is both physical and psychological. "Places are also interpreted, narrated, perceived, felt, understood, and imagined” (Gieryn 2000).

No assessment to determining place quality will be adequate unless it addresses the significance of the people's psychological connection with places; sustaining the meanings and identity of urban elements and icons is very important, as they contribute to both a sense of community and a sense of place (Hull 1992). Therefore, in any regeneration effort, it is imperative to understand the level and form of attachment and the meanings associated with the places in order to unravel their significance.

\section{$\underline{\text { Built environment }}$}

A "lived-in" heritage site is one where the community claims to have a strong social, spiritual, and cultural association (ICOMOS 1999). The study of the built environment is particularly important for such places, where people have settled, modified, and altered their spatial configuration over time according to their needs and will. The intergenerational aspect of sustainability is important in such a built environment, as it not only comprises a record of human activities but also of their values and ideologies; it is evidence of a material culture manifested in the landscape and thereby reflecting how humans relate to their surroundings. In post-disaster reconstruction planning, the designed spaces can only turn into places when the community's affective perceptions and functional needs are instilled in them (Lawrence and Low 1990)

\section{$\underline{\text { Socio-cultural environment }}$}

Culture is a "set of distinctive spiritual, material, intellectual and emotional assets of the community or group of people", as well as its "art, literature, lifestyle, values, tradition and beliefs" (UNESCO). This comprehensive definition of culture refers to the cultural heritage in all its forms and takes into account the diversity of cultural expressions. Thus, a culturally based reconstruction can be understood as an action assisting the growth of a group identity fostered by social patterns unique to the group (Zimmermann 2017). In the post-disaster reconstruction context, the intangible cultural heritage and sense of belonging plays an important role in rebuilding people's identity, and traditional knowledge systems and practices are a critical source of resilience and an expression of a community's livelihood. In most cases, the concept of intangible cultural heritage is limited to the traditional knowledge itself, without paying due consideration to its intergenerational transmission, to its socio-cultural meanings and contexts. However, both transmission and socio-cultural meanings and contexts are key to sustaining the community's culture.

\section{$\underline{\text { Economy }}$}

Disasters have widely been accepted as "windows of opportunity" for communities to be improved through restorative efforts. Regenerating and uplifting the social capital can help reduce the vulnerabilities of the affected communities (Cannon et al. 2003). In 2006, William Jefferson Clinton, who was appointed the United Nations Secretary-General's Special Envoy for Tsunami Recovery, stated that "a sustainable recovery process relies on reviving and expanding private economic activity, employment, and securing diverse livelihood opportunities for the affected population", and a livelihood broadly comprises the capabilities, assets, and activities that are required for the living and functioning of a community.

\section{Contextual framework: The heritage settlement of Khokana, Nepal}

Khokana, one of the fifty-two traditional settlements of the Kathmandu Valley, is a tiny Newari settlement situated about 7-8 kilometres south of Kathmandu. Embracing an exquisite blend of nature and culture that is manifested in its natural resources, compactly built form, and HinduBuddhist socio-cultural values, the village is located in the hills and squeezed between the Bagmati and Nakkhu rivers. Covering an area of approximately $3.2 \mathrm{~km}^{2}$, Newari's 
own tradition and culture subsist in the village, where a medieval settlement pattern, system of drainage and chowks (open market areas) have been retained. Renowned for producing mustard oil according to old traditions, Khokana is also listed as a tentative UNESCO's World Heritage site since 1996, which includes the "vernacular village and its mustard oilseed industry heritage" (Government of Nepal 1996).

Geographically located in a "man-made treeless zone", Khokana has a dense and compact settlement pattern with a distinct arrangement of courtyards. A concentric structure is clearly visible in its landscape, with the temple marking its center. This temple and the rest of the dwellings form the boundary of the first circle. The second part, built around this inner circle, consists of the agriculture fields, where paddy, maize, wheat, corn, and oilseeds are produced. They are terraced structures on the steep hillsides of the higher-situated town, forming an alluring landscape. The third circle consists of the large forest area surrounding those fields, that offered extra protection against possible invasion in the past (Fig. 2).

\section{Demography}

Khokana is predominantly an agricultural-based community where men also engage in activities such as mustard oil production, wood carving or sculpture, while women perform activities such as carpet weaving, sewing, or wool spinning during their free hours (Table 1).

Khokana community's tangible values and the preearthquake qualities of its urban fabric

Before the earthquake, Khokana appeared as a cluster of houses, closely packed together in the middle of a dense green field. The village is arranged along a wide cobbled street, with houses made of exposed light-coloured bricks and mud mortar. The brick houses are lavishly decorated with magnificently carved windows of typical "Newari" craftsmanship. These details, along with the street paving and the existence of social spaces in the form of squares and courtyards, were signs of the village's prosperous past.

The remains of the three gates, locally known as Dhokas, serve as entrances to the heritage settlement of Khokana. The eastern gate currently marks the main entrance to the village and it contains a bus stop, while the northern gate connects the route used for funerals, and the western gate is used for ritual processions.

Figure 2. Layout and surrounding scape of the historical settlement of Khokana

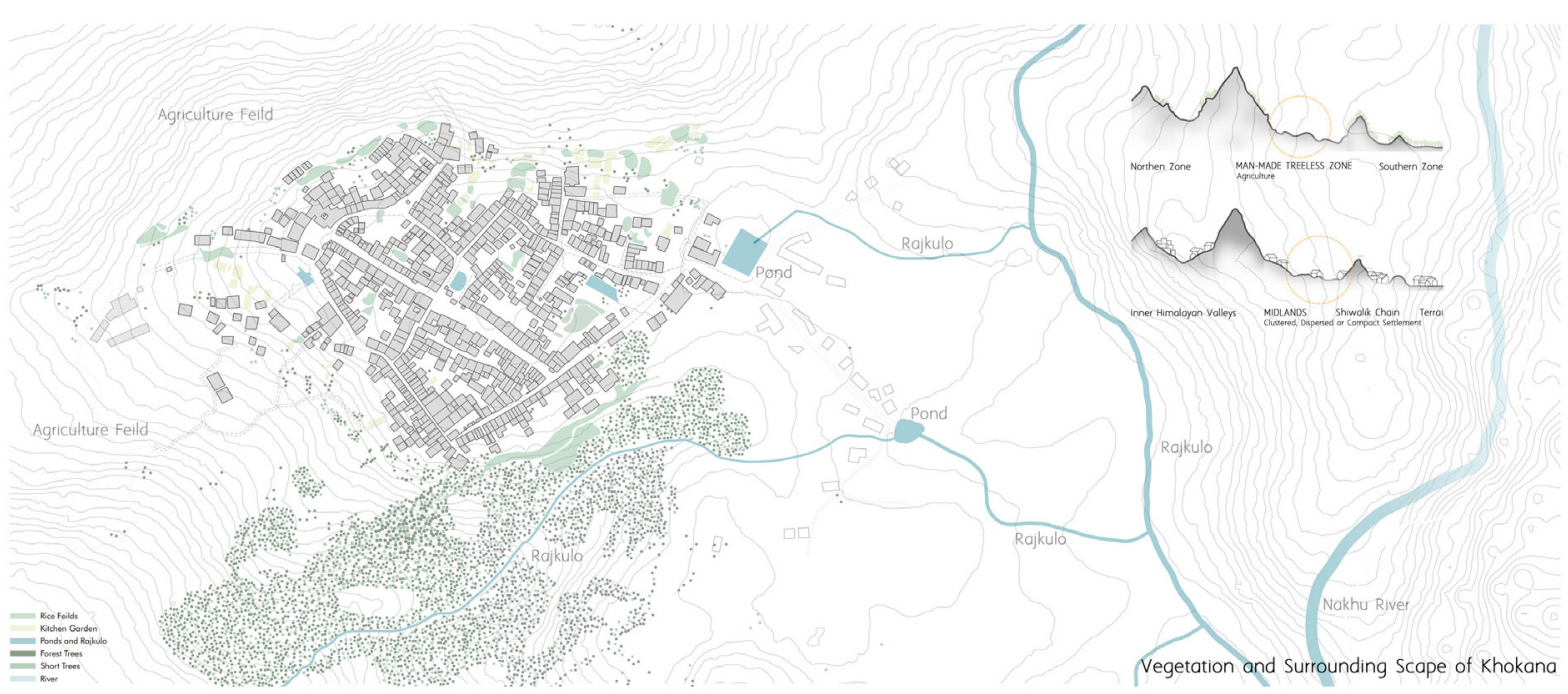

\begin{tabular}{|l|l|l|l|l|}
\hline Year & $1968-1969$ & 1975 & 2011 & 2015 \\
\hline Population & 2,546 & 2,900 & 4,927 & 4,409 \\
\hline Settlement Area & $8.29 \mathrm{Ha}$ & $8.29 \mathrm{Ha}$ & & $8.56 \mathrm{Ha}$ \\
\hline Built Space & $1.70 \mathrm{Ha}$ & & & $3.01 \mathrm{Ha}$ \\
\hline Open Space & $5.40 \mathrm{Ha}$ & & & $4.38 \mathrm{Ha}$ \\
\hline Circulation Space & $1.17 \mathrm{Ha}$ & & & $1.17 \mathrm{Ha}$ \\
\hline Gross Density & $307 \mathrm{Person} / \mathrm{Ha}$ & 350 Person/Ha & & $515 \mathrm{Person} / \mathrm{Ha}$ \\
\hline Number of Houses & 335 Families & 500 Houses & 1056 Household & 944 Household \\
\hline
\end{tabular}




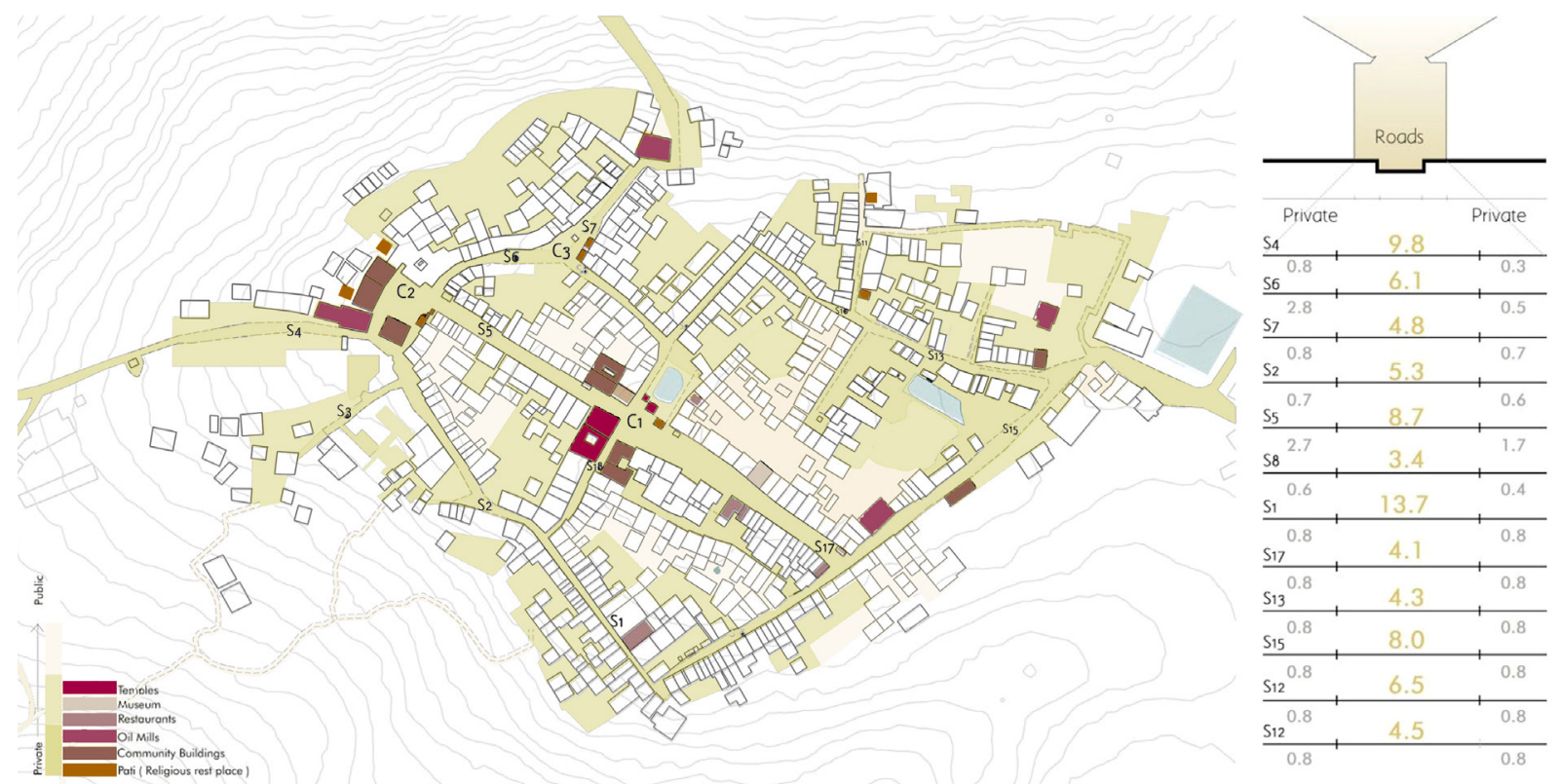

Figure 3. Hierarchy in the spatial configuration and privacy mapping of Khokana

\section{Spatial hierarchy}

Khokana is often also categorized as a courtyard village, as the built network consists of a series of narrow alleys and smaller corridors leading to a diversity of courtyards. This generates a maze of open spaces which is a unique feature of the urban pattern of Khokana. The urban fabric forming the backbone of the settlement reflects a varying degree of privacy and is defined by two key elements: firstly, the residential units closely clustered around the inner shared courtyards; and secondly, the public squares connected by the network of streets.

There are three main public squares in Khokana, each of them built in close relationships with religious and social activities. The link between religion and the squares is marked by the fact that all these squares accommodate shrines or images of a deity, alongside traditional water systems and small religious structures, known as paatis. The squares usually host several other public buildings, such as community halls or oil mills (Fig. 3).

\section{$\underline{\text { Traditional building culture and architecture }}$}

The common lifestyle, the use of locally available building material, and traditional construction techniques have resulted in coherent architectural forms throughout the settlement of Khokana. The decoration of the intricate timber windows, doors, brackets, vertical posts and cornices demonstrates the local craftsmanship of the village. The architectural vocabulary of Khokana is in the first instance expressed through its building materials:

Figure 4. Typical household unit layout in Khokana

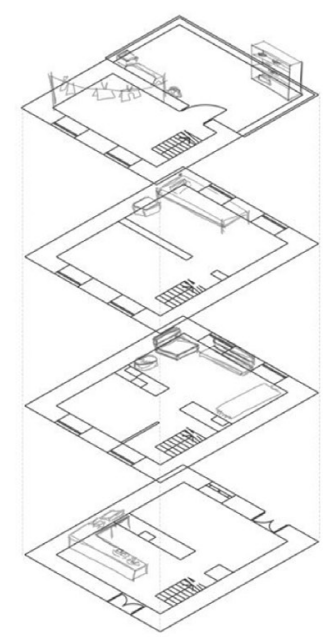

Plan of Typical House

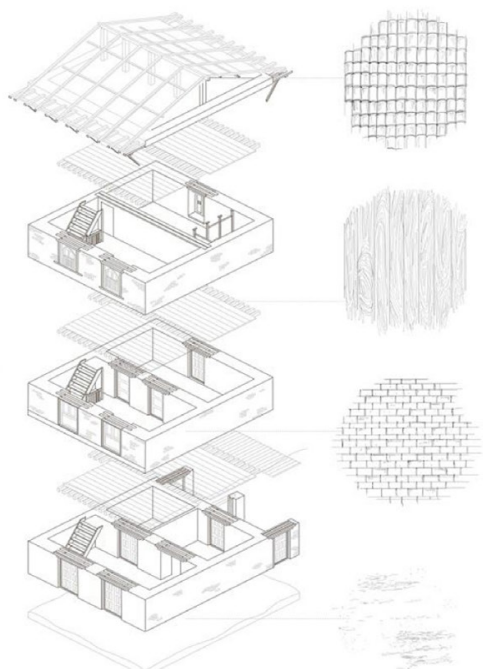

Construction Material Used
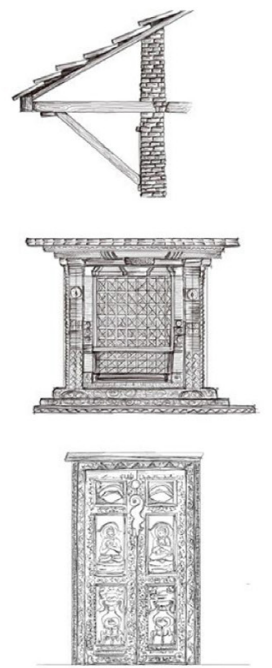

Building Element
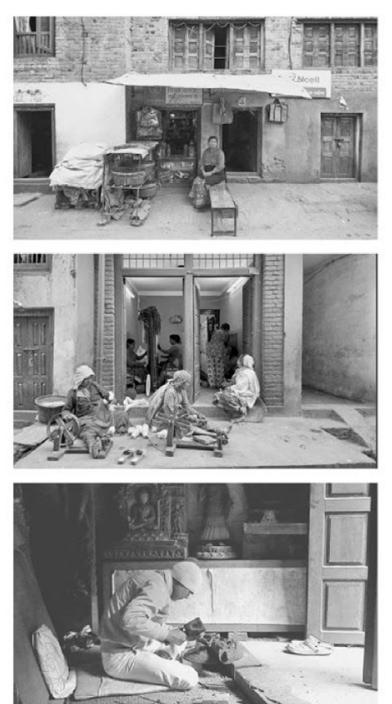
1. Walls

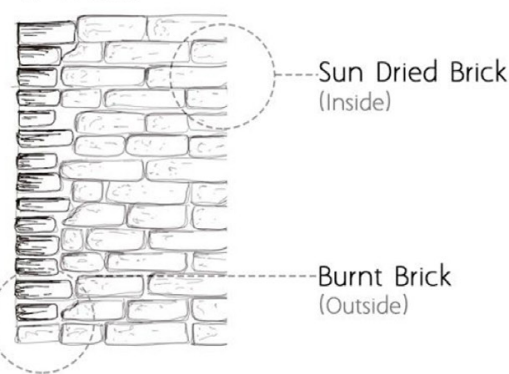

2. Windows

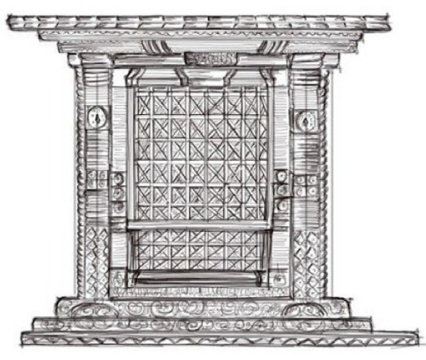

3. Doors

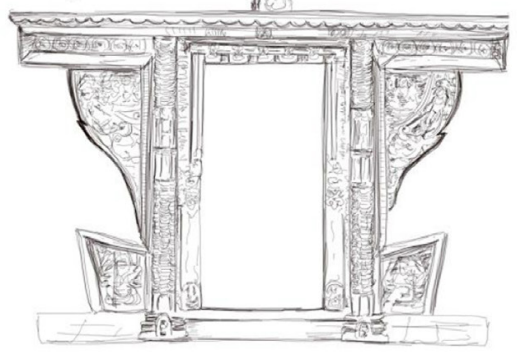

Figure 5. Traditional architectural features of the buildings in Khokana

brick, stone, mud, and timber. There is a continuous façade of fair brick masonry along the stone-paved streets, covered with a temporary additional layer of hanging agricultural products that change with the seasons, adding dynamism to the streetscape.

The traditional houses in Khokana have a similar layout and spatial organization to all other Newari houses in Kathmandu. Traditionally a Newari house comprises three-stories built with brick façades, ornamented timber windows and doors, and overhanging timber roofs. Symmetry is achieved in the façades by paring windows along the central axis (Fig. 4 and 5). The ground floor or chedi is designated for storage, a cattle shed, or a workshop depending on the needs of the owner. The upper floors of the house are designated for private functions, with the bedroom and living room in the first and second floors respectively, while the kitchen, along with some overall storage space, is placed at the level of the attic.

The traditional houses of Khokana did not have private washrooms, as people would wash in the community ponds, water fountains, or tube wells and for their sanitary needs they would simply go to the fields. However, more recent developments in their use of space have meant that small restrooms have normally been built under the staircase or in the courtyards, for shared use with their neighbors.

The structural vertical elements of the house include brick wall foundations, generally between 45 and 75 centimetres thick, and double brick walls bound with mud mortar. The structural horizontal members of the houses include mud and timber floors and timber roofs. Another significant characteristic of the Newari architecture is its tall elevated plinths, the height of which usually varies from sixty to eighty centimetres. Traditionally known as Petis, these elevated plinths not only act as a threshold between private and the public life, but are also an important architectural element satisfying additional spatial needs of the inhabitants and hosting various household activities. The façade of the average ground floor has a fairly simple design with a series of low doors. Usually, the most decorative element of a façade in a Newari house are its elaborate San Jhya windows, which are placed on the second floor. This is its most important acess to the street, other than the door itself. Even in the simplest of houses, the windows of the second floor are always accentuated.

The traditional architecture of Khokana also includes various seismic-resistant features. The main ones are: the symmetric configuration of the traditional building, which is usually rectangular in shape; the small length-to-depth ratio of the building (mostly equal to 1.5 or less); the small and symmetrically located openings; the low height of each story; and the various timber joints (Dixit et al. 2004).

\section{$\underline{\text { Climatic response of Khokana's traditional architecture }}$}

The traditional architecture of Khokana also includes climate-responsive building strategies. While the lowceiling rooms help to heat the building during the winter, the location of the kitchen in the attic and the storage on the ground level acts as a buffer area to prevent the living spaces from overheating during the summer. The building materials used - brick, clay, and timber - provide good thermal resistance properties too.

Figure 6. Climatic responsive properties of the traditional houses in Khokana
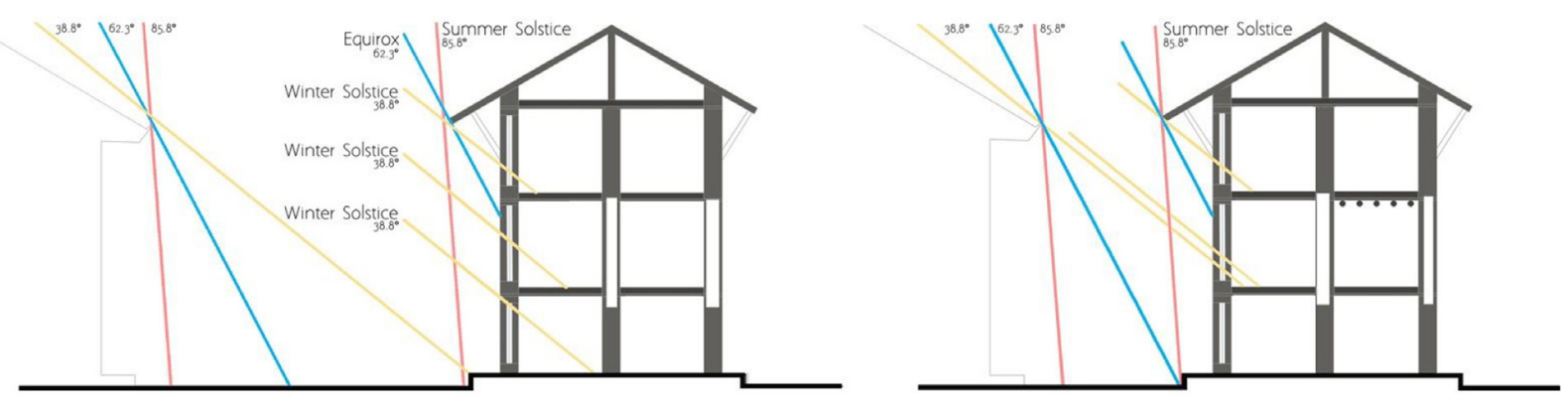

Wide and narrow street allowing solar radiation from ground floor and first floor respectively 
The external walls are usually built with two leaves of brick, where the external leaf consists of the fired brick and the internal leaf is made of sun-dried bricks with clay mortars in between to lower the U-value and increase the lag time. The thermal resistance is improved by the sun-dried bricks as they have a lower density in comparison to the fired bricks. In addition, the sun-dried bricks absorb ten to twenty times more moisture, making the indoor environment more comfortable.

The horizontal projection of the roof varies from 80 to 100 centimetres, protecting the building from severe rainfall and external exposure to the sun.

The small size of the openings (about ten percent of the total floor area) also provides thermal insulation. As most of the daily activities are carried out in open spaces, this does not limit the functionality of the interior spaces (Fig. 6).

Khokana community's intangible values

Socio-spatial phenomenology studies the urban composition of a place on the basis of its users, their identity, and their shared beliefs. The merely spatial narrative can undermine the meaning of a place. The majority of the community's daily life in Khokana revolves around its three public courtyards. They are formed at the junction of various networks of streets, and associated with numerous elements of cultural heritage.

\section{Mapping of courtyard 1}

Values and beliefs: Various cultural festivals and rituals are performed in the public courtyards. Various local festive processions start from the temple complex, where people pray, play traditional instruments in the religious covered structures known as Paati, and participate in a traditional masked dance. Apart from shaping the urban fabric of the settlement, the traditional water system, with all its attributes, also plays an important role in the culture as well as in the socio-economic activities of the community.

Streetscape: The wide road at this junction doubles up as a spillover space for the community festivals and functions. The street is characterized by a certain transition zone or threshold, shaped with a material distinct from that of the street, with an elevated plinth. While walking through the temple street of Khokana, a vibrancy is felt in the sounds coming from the temples, the chanting of prayers, traditional instruments, etc. (Fig. 7).

Mapping of courtyards 2 and 3

Values and beliefs: As courtyard 2 connects to courtyard 1, it becomes an extended route and area for various festivals and religious processions. Due to the presence of the main social structure of the village here (the Guthi), this courtyard is used for organizing feasts and performing art (dance, ballet, and music) during almost all community functions during the year. However, courtyard 3 is primarily used by the surrounding households for water needs to perform daily household activities such as washing, bathing, etc.

Streetscape: The street pattern, aligned with continuous buildings on two sides leading from courtyard one to courtyard two, slopes down drastically, and the overall morphology of the settlement on the northeast is apparent as one walks through these streets (Fig. 8).

Figure 7. Collective memory mapping of Courtyard 1

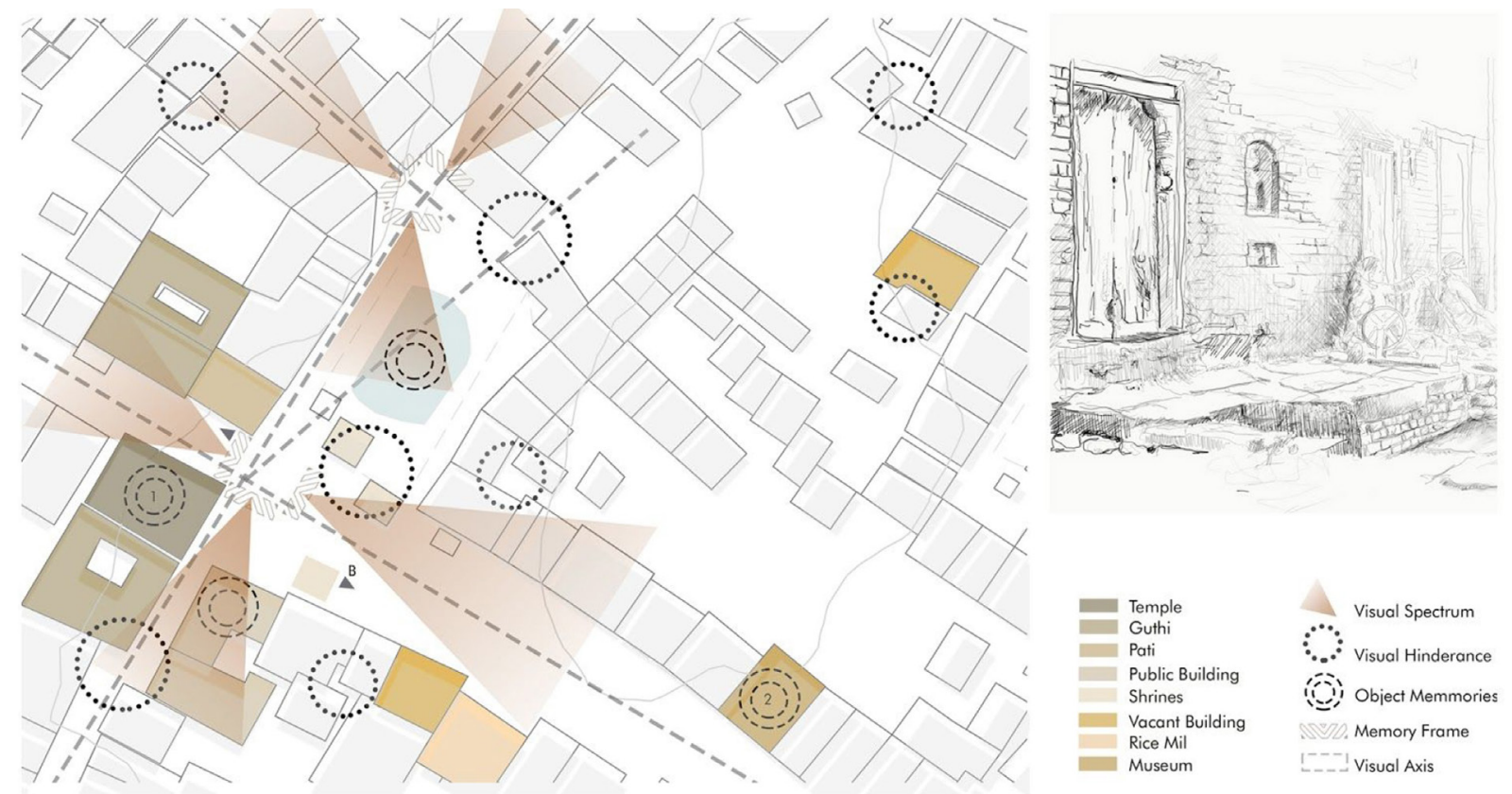



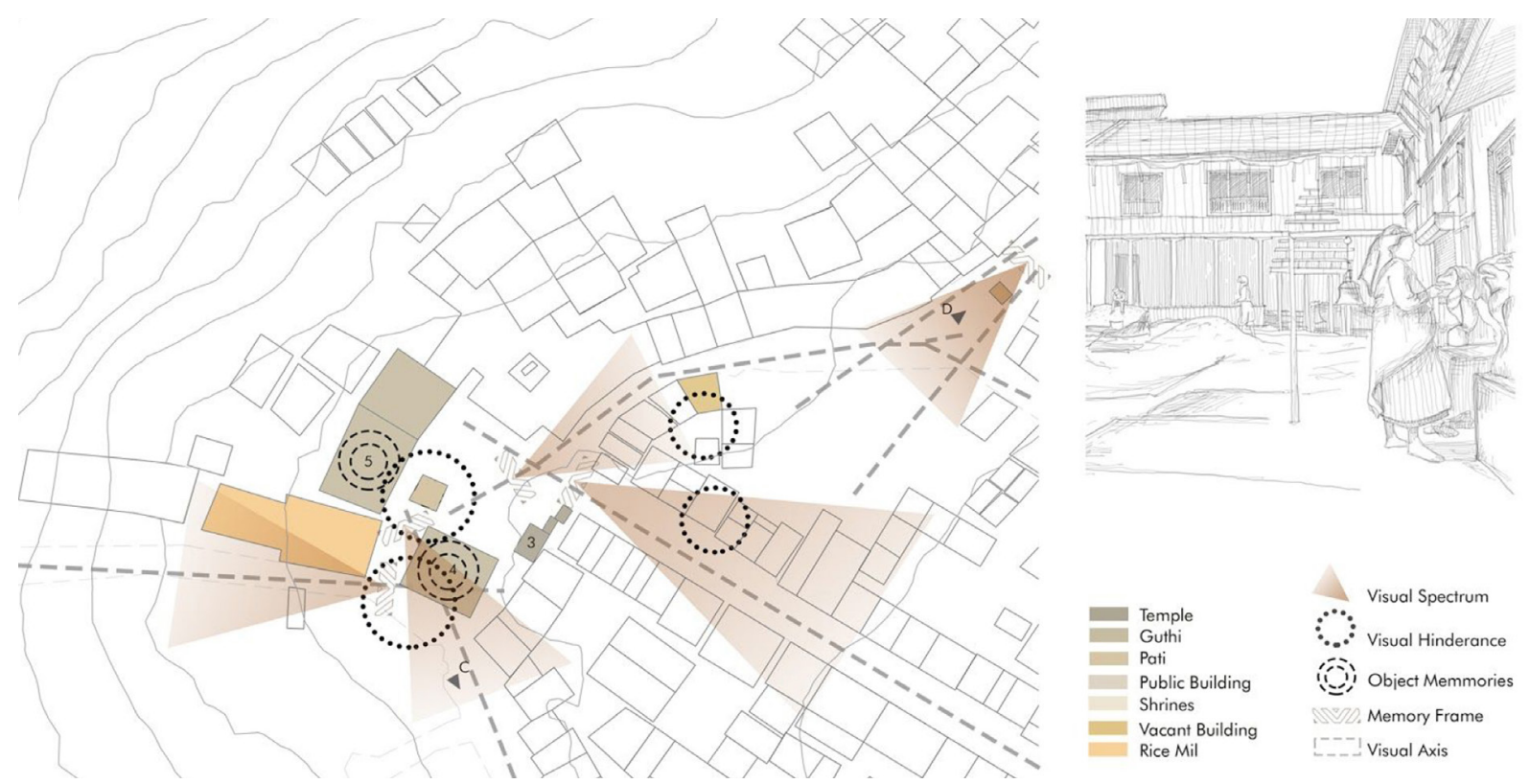

Figure 8. Collective memory mapping of Courtyard 2 and Courtyard 3

\section{Khokana Community's socio-economic culture}

Being a farmer does not only entail agricultural activities. In most farming families, other family members engage in other professions such as wood carving, carpet weaving, running a shop, etc. to earn extra income, as the average agricultural land owned by families in the village is only enough to satisfy their for half a year. This has frequently resulted in a shift in building typology from purely residential to mixed-use. In such cases, the ground floor of the residential building is linked to the profession, while the remaining floor above is reserved for private life (Fig. 9).
Khokana is famous as a producer of mustard oil. The village established its policy of intensifying mustard oil manufacturing as its main industry during most of the agricultural off-season. The tradition started 500-600 years ago. Over time, the mustard oil industry of the village has become the settlement's living heritage. There are four traditional mustard oil mills in the village, all located at its periphery. The spatial requirements of a typical oil mill in Khokana are: storage space for mustard seeds, an area for cleaning, grinding and heating the seeds, a seed compressor (in this case the traditional oil compressor designed from a wooden log, which works on the weight applied by the worker), and a storage space for the extracted mustard oil.

Figure 9. Various residential typologies mapped

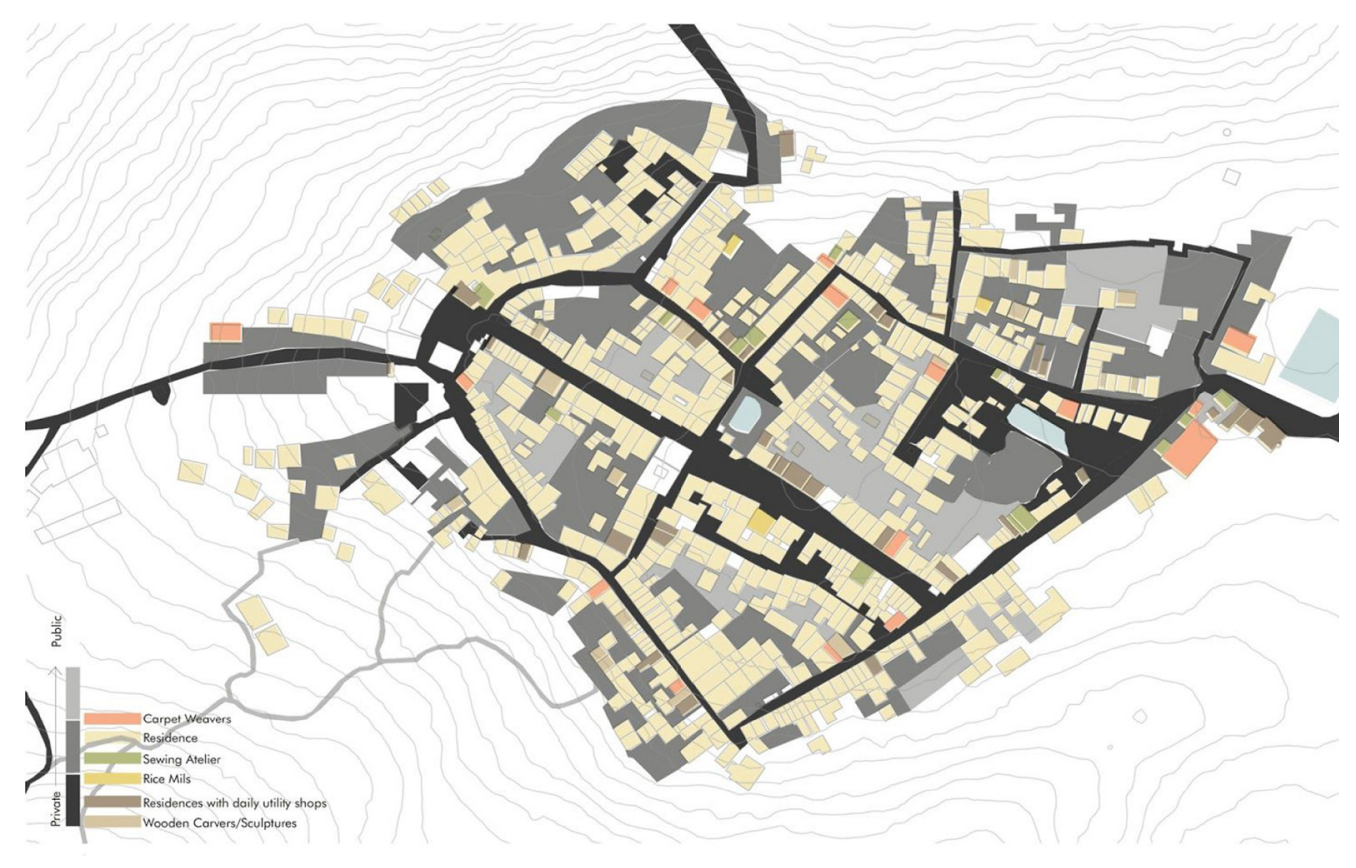



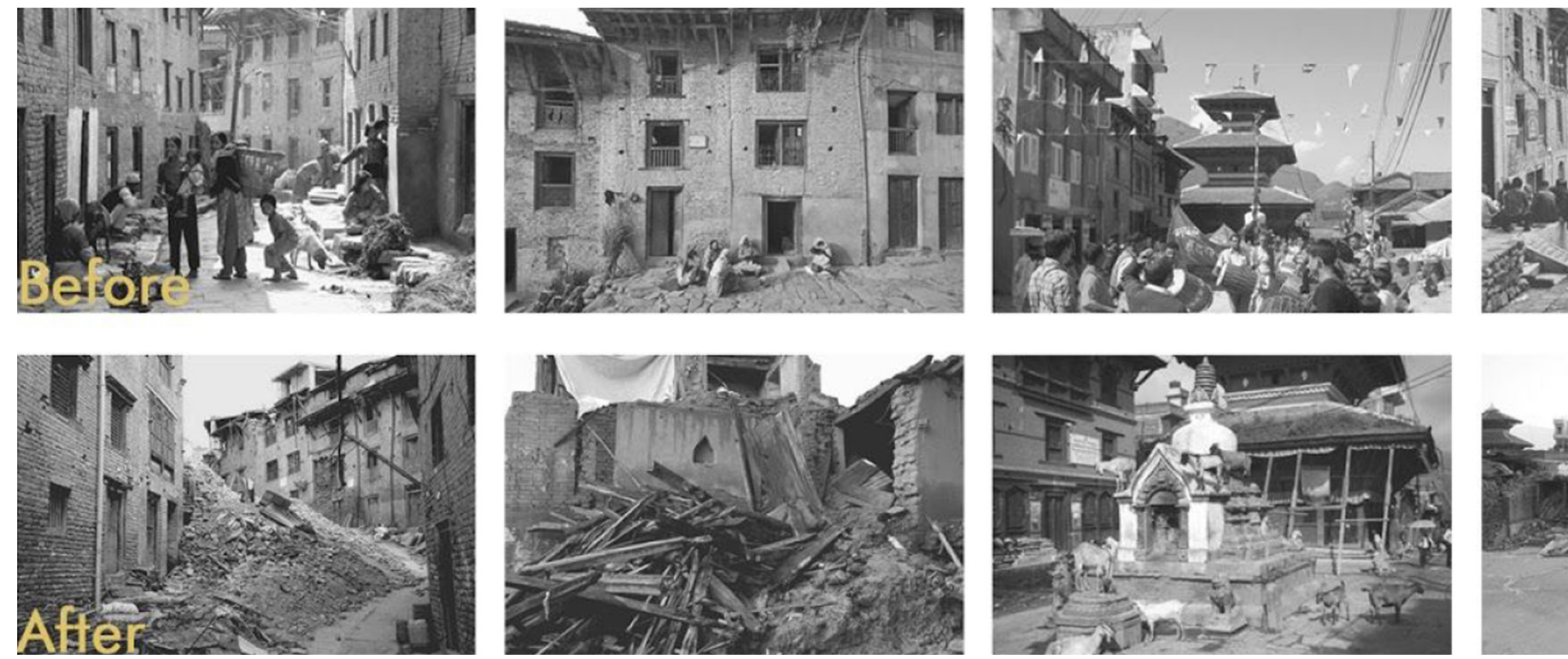

Figure 10. Physical infrastructural damage after the 2015 earthquake

Spatial assessment of Khokana community after the 2015 earthquake

In the aftermath of the 2015 Nepal Earthquake, the built, cultural, economic and social environment of Khokana was severely impacted. As the earthquake struck when most of the inhabitants of the village were working in the fields, human casualties were reduced. However, Khokana suffered a significant loss of cultural heritage, both tangible and intangible (Fig. 10).

Around $80 \%$ of the existing houses were declared unfit for habilitation after the earthquake. Among the affected residents were people having to live dual lives; sleeping in the temporary residences around the outskirts of the village, and returning to their partially destroyed homes during the day

Due to the lack of physical infrastructure, the economy of the village has suffered a severe decline. At present, only one of the four traditional oil mills of Khokana is operating. As a result, the oil produced with modern equipment in Kathmandu Valley has taken over the traditional oil market of Khokana, consequently posing a threat to its survival.

Khokana is also struggling to preserve its identity and cultural practices due to the loss of its historic fabric. Its religious, social, and cultural spaces were heavily damaged.

Impact assessment of the buildings (Table 2 and Fig. 11)

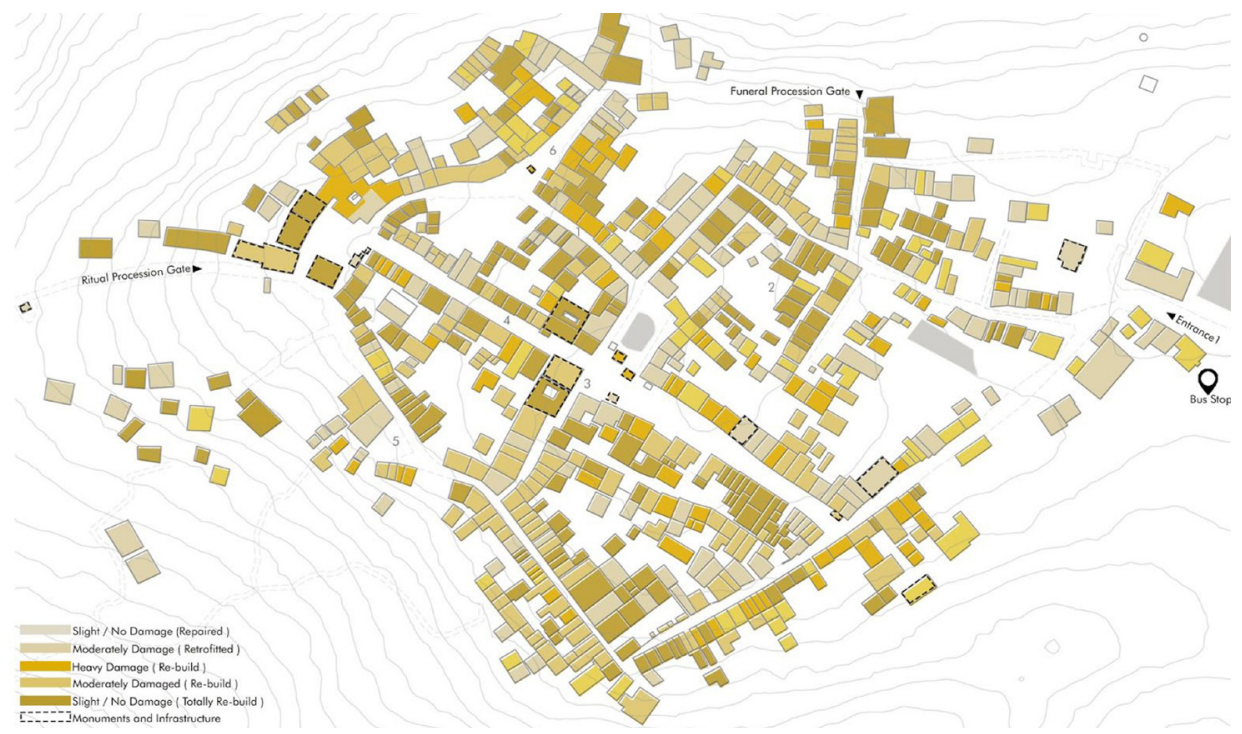

Figure 11. Damage assessment map of Khokana after the 2015 earthquake 

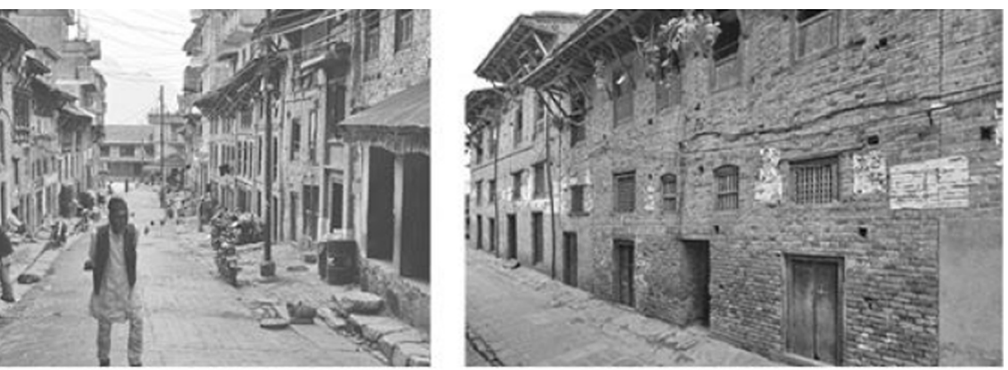

Table 2. Statistics on the building damage
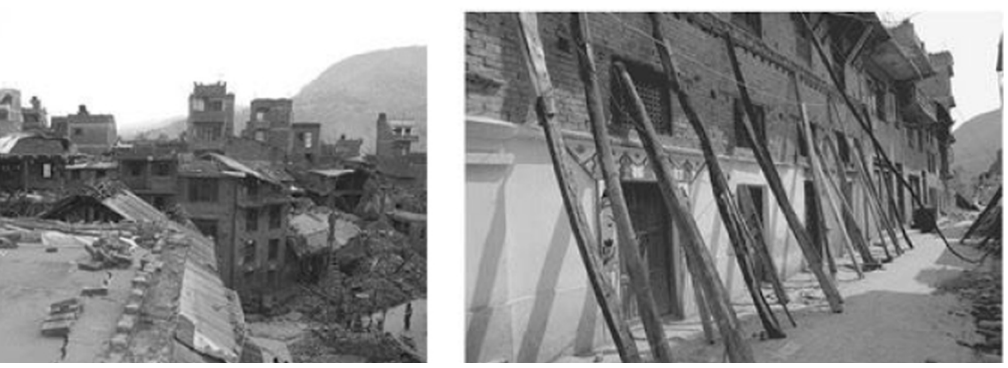

\begin{tabular}{|l|l|l|}
\hline \multicolumn{2}{|l|}{ Damage Grade } & Houses affected \\
\hline Completely collapsed & DG5 & 202 \\
\hline Partially collapsed & DG4 & 228 \\
\hline Highly damaged & DG3 & 82 \\
\hline Moderately damaged & DG2 & 74 \\
\hline Slightly affected & DG1 & 145 \\
\hline Total & & 731 \\
\hline
\end{tabular}

Table 3.Statistics of the physical infrastructure

\begin{tabular}{|l|l|l|l|l|}
\hline $\begin{array}{l}\text { Infrastructure } \\
\text { type }\end{array}$ & $\begin{array}{l}\text { Private } \\
\text { structures }\end{array}$ & $\begin{array}{l}\text { Public } \\
\text { structures }\end{array}$ & $\begin{array}{l}\text { Religious } \\
\text { structures }\end{array}$ & Total \\
\hline $\begin{array}{l}\text { Number of } \\
\text { existing structures }\end{array}$ & 731 & 12 & 14 & 757 \\
\hline $\begin{array}{l}\text { Number of } \\
\text { structures to be } \\
\text { reconstructed }\end{array}$ & 512 & 10 & 4 & 526 \\
\hline $\begin{array}{l}\text { Number of } \\
\text { structures with } \\
\text { minor damage }\end{array}$ & 219 & 2 & 10 & 231 \\
\hline
\end{tabular}

Figure 12. Damage assessment of each building material after the 2015 earthquake

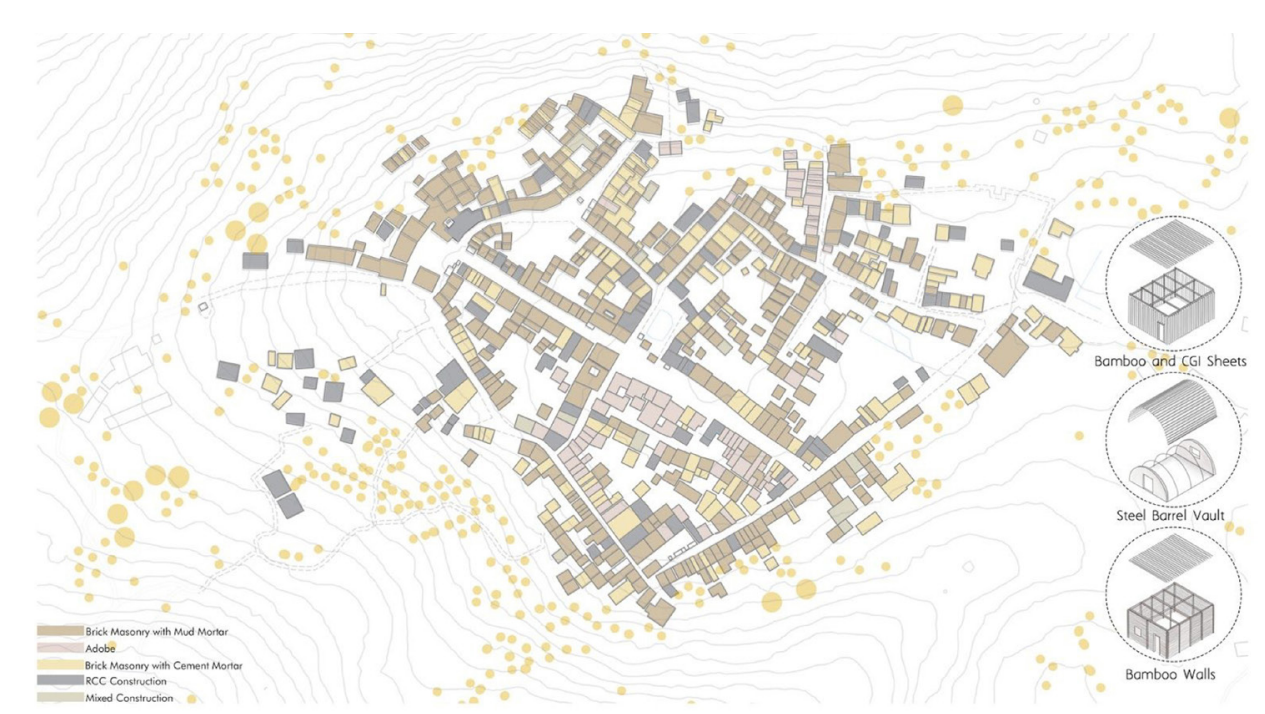

Table 4. Statistics on building materials

\begin{tabular}{|l|l|l|l|l|l|l|}
\hline Building material & Adobe & $\begin{array}{l}\text { Fired brick and } \\
\text { mud mortar }\end{array}$ & $\begin{array}{l}\text { Brick and cement } \\
\text { mortar }\end{array}$ & $\begin{array}{l}\text { Reinforced } \\
\text { cement concrete }\end{array}$ & $\begin{array}{l}\text { Mixed } \\
\text { structure }\end{array}$ \\
\hline Existing number of houses & 60 & 385 & 186 & 86 & 14 & 731 \\
\hline Houses damaged In the earthquake & 56 & 307 & 90 & 47 & 12 & 512 \\
\hline Damage percentage & $93 \%$ & $80 \%$ & $54 \%$ & $85 \%$ & $80 \%$ \\
\hline
\end{tabular}

Assessment of the impact on cultural heritage

The cultural heritage of Khokana includes privately-owned traditional residences, public buildings (community halls, mustard oil mills, etc.), monuments (temples, shrines, paatis, etc.), and the traditional water systems. As Khokana was established as an independent rural settlement in the $15^{\text {th }}$ century and people built their residences with no need for a formal authorization, it is now facing problems of land ownership which have delayed the reconstruction process.
(Table 3)

\section{Assessment of the impact on building materials}

In Khokana, 445 buildings out of the 731 that were surveyed, which is almost $60 \%$, are low-strength brick masonry structures built in a traditional way. About 186, or $26 \%$, were built with load-bearing brick masonry with cement mortar and 86 , or $12 \%$, were built with reinforced cement concrete (Table 4 and Fig. 12). 

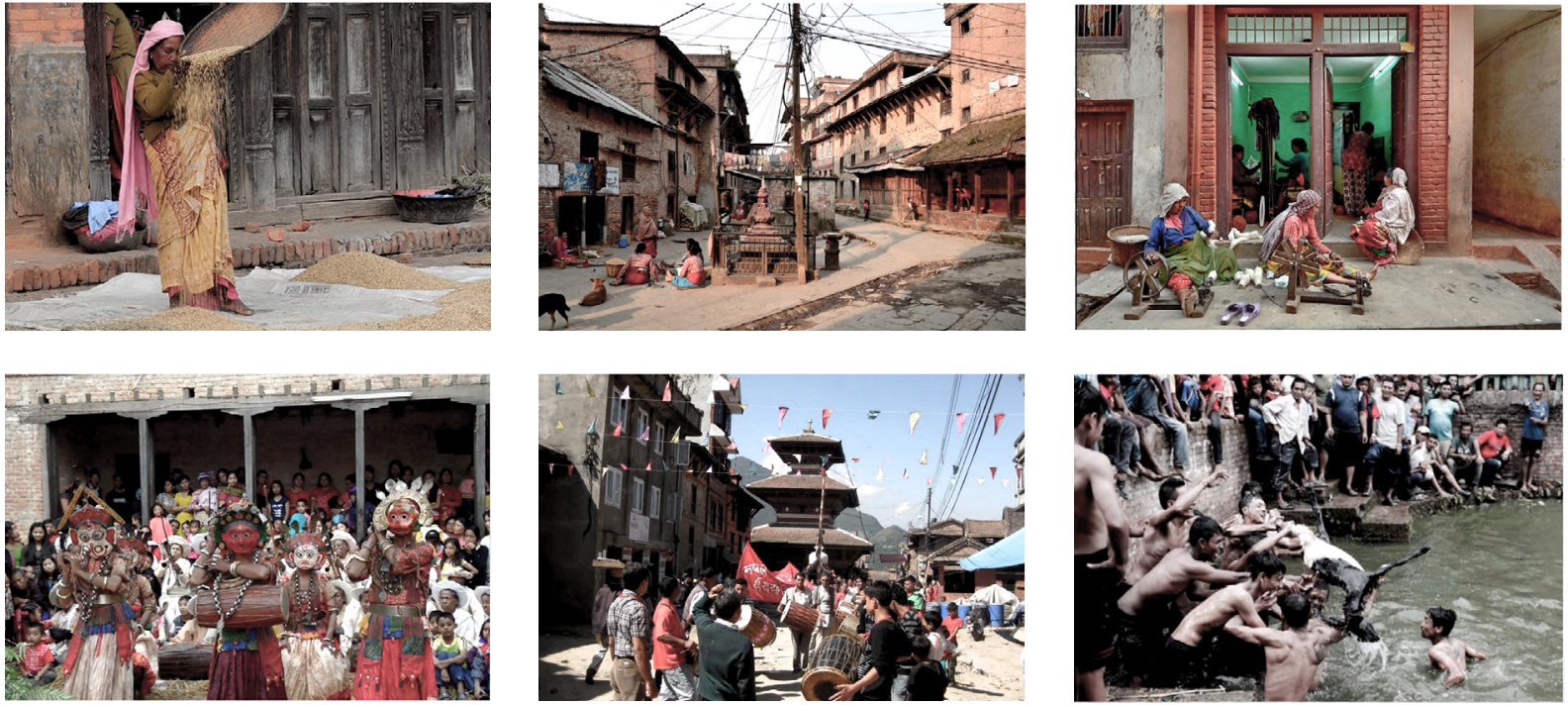

Figure 13. Spatial and architectural elements which are crucial for Khokana community's identity

\section{Discussion of the results and proposal for reconstruction}

The heritage settlement of Khokana was a paradigm of the traditional Newari architecture, culture, and lifestyle. The inhabitants of the village took pride in their inherited legacy. This was clearly seen in the continuity of traditional practices, spiritual values and rites in the village. However, the settlement, which was once regarded as "the living museum" of these traditions, today remains deserted and lifeless. The $2015 \mathrm{Nepal}$ earthquake has not only damaged the physical fabric of the settlement, but has also impacted its socio-cultural heritage. Some structurally unstable houses that still stand in this virtual ghost town are kept only by aligning heavy timber beams on their damaged façades. While the locals, with government support, have finally come together to build back their lives and their settlement, the challenge now is to revitalize the settlement while conserving its heritage, traditions, and social practices (Fig. 13).

One's perception of a place can be expressed in various ways, varying from human life, personal experiences, emotions, events, etc. In Khokana, aspects such as the distinct aroma of mustard seeds, the sound of the temple bells or the people walking and chatting on the street defined the "way of life" of the village, the relation of the people with their spaces. Nevertheless, after almost eighty percent of Khokana physical structures were declared unfit for habilitation after the 2015 earthquake the question now is: how can the reconstruction offer an opportunity to reinterpret its cultural landscape and traditions while meeting contemporary challenges? (Fig. 14).

The following are the important features, derived from studying the tangible and intangible attributes of Khokana, that should be pursued in the reconstruction plan for the village (Fig. 15):
- The maze of open spaces (tangible aspect): The clear spatial hierarchy in the village's layout includes varying sizes of open spaces and courtyards surrounding the temple complex. This hierarchy of open spaces is a distinct element of the identity of the place and reflects the essence of the community's social activities, beliefs, and privacy needs.

- Interior space of the dwellings (tangible aspect): The internal arrangement of the houses of Khokana is also based on privacy and purity gradients. The materials and spatial organization of the buildings further compliment the local climate and the available resources.

- $\quad$ Streetscape (tangible aspect): The vibrant and active streetscapes of Khokana are related to a coherent set of traditional architectural elements, such as the intricately carved windows on the brick facade, low height doors, extended plinths, sloped tiled roofs, wooden brackets, posts, building heights, etc. These patterns that one sees as a part of daily life produce an image of stability and permanence in the community. Such a social connection with the spaces enhances a "sense of belonging".

- Retaining the local economy (intangible aspect): Khokana's secondary sources of income are its oil mill industry, carpet weaving industry, wooden carving ateliers, etc., which are an integral part of the community's cultural heritage. These traditional knowledge systems should therefore be preserved by introducing enhanced workable spaces that help to empower the community and retain its integrity. 


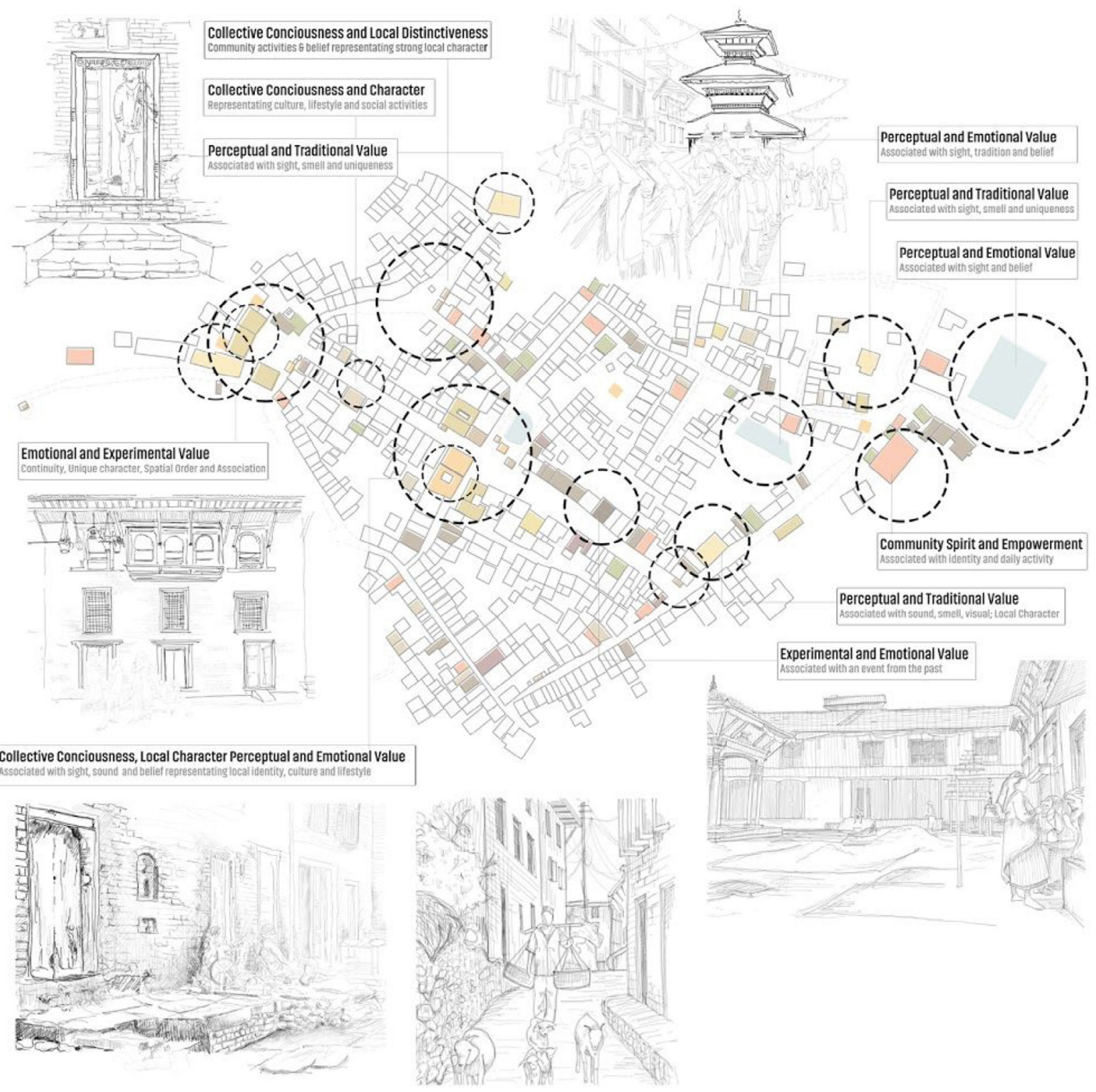

Figure 14. Emotional, experimental and perceptual aspects associated with the place

Figure 15. Vacant plots and existing building blocks after the 2015 earthquake

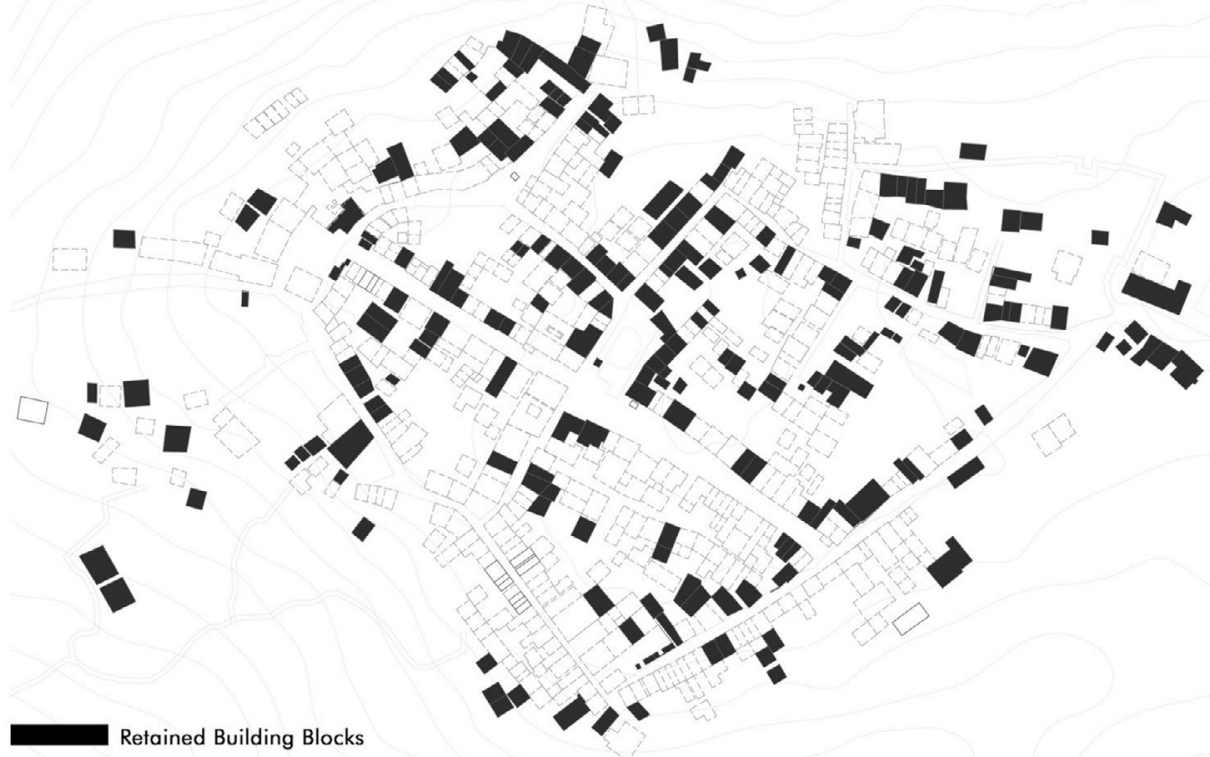


The reconstruction of Khokana can also be seen as an opportunity to enhance the cultural landscape with placebased strategies that complement the existing cultural heritage and lifestyle of the settlement. Examples include the following:

- Potential tourist hub: Located amidst various tourist hubs, Khokana can potentially attract tourism by creating spaces such as traditional homestays, craft centers, agro-tourism centers, vocational schools, etc., that not only boost the local economy, but also showcase its unique cultural heritage.

- Reinforcing the existing heritage: The existing public spaces, especially the public courtyards and the traditional water systems, can be intensified as dynamic recreational nodes with added activities for re-energizing both its spatial and perceptual experience.

- Introducing infrastructure facilities: The village lacks basic infrastructure facilities such as wastewater management, sewage treatment, and adequate water supply. These facilities can be integrated into the reconstruction plan for the efficient functioning of the community. Furthermore, the use of seismic strengthening strategies in the reconstruction process, while preserving the traditional architectural characteristics of the village, can help build community resilience.

- Boosting the economy: The street space of Khokana can be enhanced by introducing economically profitable activities on and around areas with potential (nodes and squares). The renewal and adaptive reuse of unused and abandoned buildings along the streets can be initiated by assigning various functions to them.

\section{$\underline{\text { Reconfiguration of the physical enclave }}$}

Reinstating spatial hierarchies: the new clusters to be introduced in the post-disaster vacant plots of the settlement should be planned and positioned so that they strategically form courtyard spaces to not only retain the local character of the settlement but also to serve as relief zones, if needed. These courtyards can then be connected to each other, and subsequently opened up to larger squares. Alleyways in between the housing clusters can be planned for easy access to courtyards, and they could also act as an escape route during a crisis. Fig. 16 presents the settlement plan for Khokana after the 2015 Earthquake, which is designed in three stages:

Stage 1: The initial clustering is done by considering the average footprint of the houses according to the family sizes that existed in Khokana before the earthquake. The buildings to be repaired or retrofitted (as per the damage assessment mapping) are retained in their former places, whereas the ones to be entirely reconstructed are organically clustered around them.

Stage 2: Potential nodal points are identified at various junctions that aim to serve as relief zones or as social spaces. The clustering is re-designed to form a small semiprivate courtyard for performing daily life activities which are further interconnected by defined pathways. This helps develop a hierarchy of open spaces around the village, serving as multi-purpose activity zones while keeping the traditional spatial configuration alive.

Stage 3: The plan is further enhanced by adding the local feature of small narrow alleys, but modifying their size so they can also act as effective escape routes if necessary. These alleys are planned to reach either the arterial streets or the larger public squares, for safety. The scattered building layout plans are modified into a compact bundle form to increase the resistance and stability of building in

Figure 16. Site planning strategy for the Khokana community. Stage 1, 2 and 3.
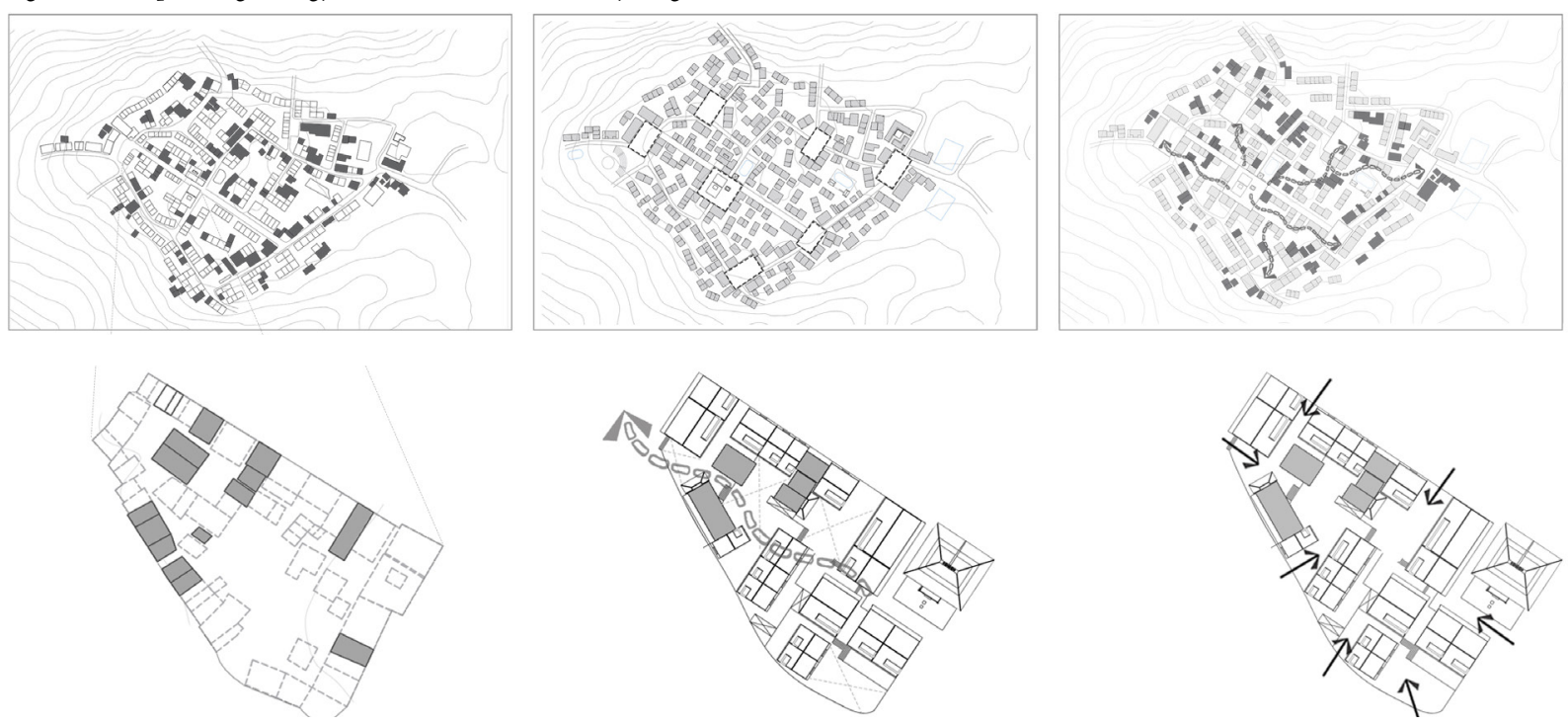
earthquakes. They are designed and aligned into simple rectangular forms with common walls, to form a strong resistant bulk mass.

Contemporizing the traditional Newari architecture: intervention in terms of structure and building materials to create a seismically resilient built environment is vital in the case of Khokana. However, materials should be selected so as to keep Khokana's architectural coherence intact. The traditional household units could be reconfigured as follows:

- Building layout: it should follow the current symmetrical pattern. The fundamental ratios between the wall thickness, maximum length, and height of the walls should also be respected.

- Seismic-resistant techniques: the provision of seismic bands on the plinth level, sill level, lintel level, and roof level improves the load-carrying capacity of the building tremendously during an earthquake.

- Material selection: use of contemporary materials like interlocking brick and compressed stabilized earth brick can be used to create a box effect on the rest of the structure, but it is important that the joints in the corners and with the transverse partition walls are done adequately to increase the efficiency of the structure. Highly resistant and ductile materials like bamboo could be used for vertical posts, brackets (cladded with 2-millimetre ply board) and roofing framework for the revised traditional architecture.

- Installing infrastructure facilities: infrastructure facilities like wastewater management, sewage treatment, rainwater harvesting, etc. could be integrated too. (Fig. 17).

\section{$\underline{\text { Reconfiguration of socio-cultural aspects }}$}

Life in the existing public spaces, especially in the public courtyards and in the vicinity of the traditional water elements, and around the temple, community buildings, etc. can be intensified, creating more dynamic recreational nodes with added activities for re-energizing their role.

\section{Reconfiguration of the economy}

Any structures required for an effective functioning of the local mustard oil production can be introduced. A market infrastructure could be also implemented, where the mill workers could sell their extracted oil product to both the village inhabitants and outsiders. Adequate infrastructural provision for the carpet weaving community and the wood carving community can be proposed, in a way that also provides the locals with an environment to teach, learn and sell their crafted products.

New activities could be promoted in and around the most adequate areas for economic activity (like nodes and public squares). Located amidst various tourism hubs surrounding
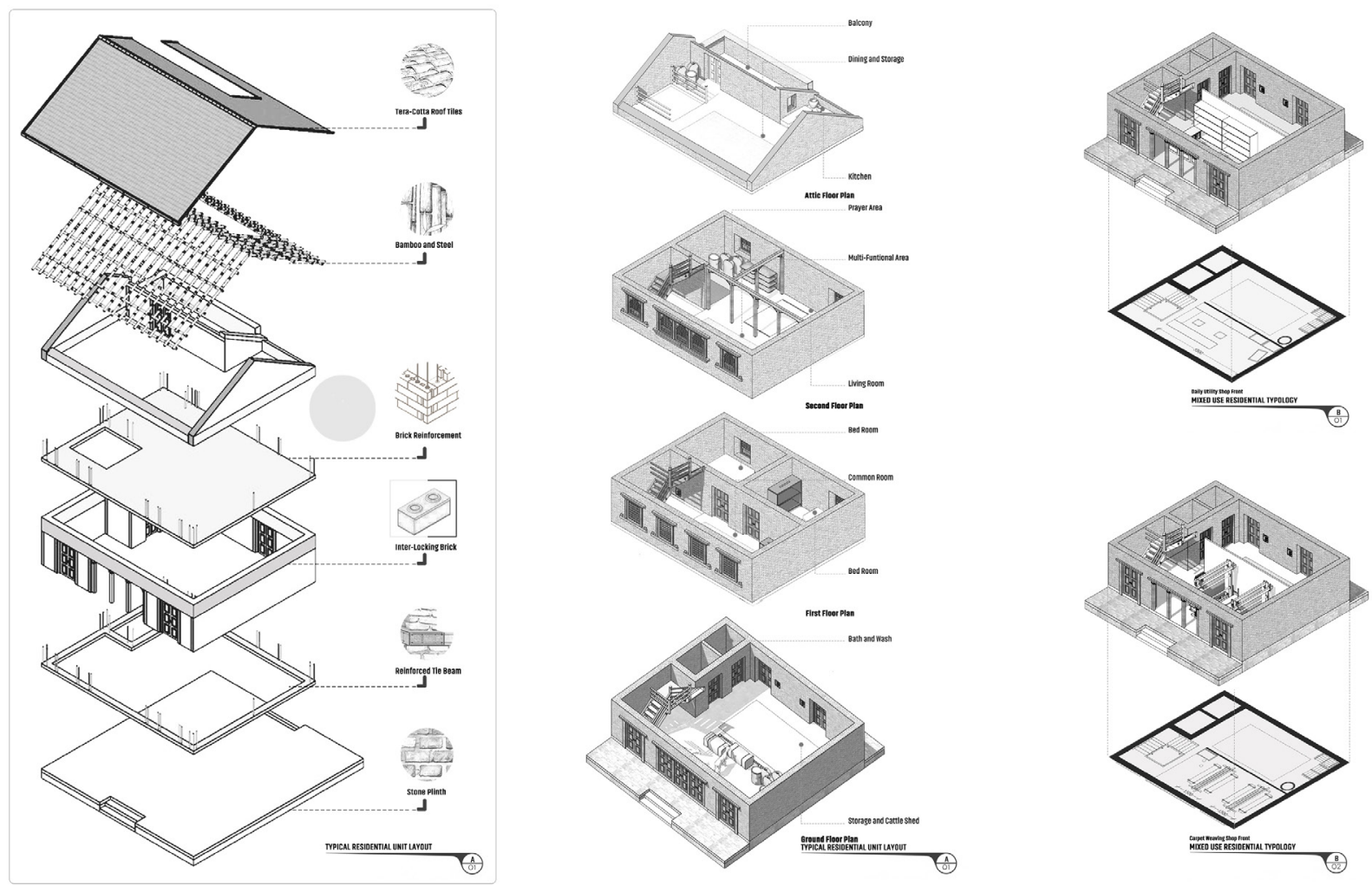
the settlement, Khokana can potentially attract tourism by introducing spaces such as traditional homestays, craft centers, agro tourism centers, vocational schools, etc., that could not only boost the local economy but also help showcase its unique cultural heritage.

\section{Conclusion}

This study emphasizes how post-disaster reconstruction should be considered not just as something physical, but as a part of a holistic view, where the community and its unique social, cultural, and economic relationships are also considered.

Traditional built, social, and cultural environments evolve according to the needs, practices and activities of each community, which provide meanings to each place. The unique collection of qualities and features of a particular place fosters human association and a sense of belonging, which therefore plays an important role in a cultural context by integrating people and places. However, in most reconstruction projects it is often seen that the designs are based on presumptions and abstract notions rather than on a clear understanding of the needs and aspirations of the specific community. This itself sheds light on why such projects often fail.

This paper takes the case of the heritage settlement of Khokana to study how the community functions within its context and to propose design strategies that could contribute to its sustainable reconstruction. The aim was to emphasize the need for a 'place-based' or 'contextbased' reconstruction process. In the course of the study, various tangible and intangible assets of the community are identified which serve as a basis for the proposed strategies. The proposed actions address community resilience through planning and reconstruction, but also through the preservation of cultural heritage and initiatives for socioeconomic revitalization.

\section{Bibliography $\mid$ Bibliografía | Bibliografia}

Baer, Sebastian Norbert; Sabbioni, Cristina; and Sors, Andre. 1991. Science, Technology and European Cultural Heritage. Oxford: Butterworth-Heinemann.

Beer, Michael; Kougioumtzoglou, A Ioannis; Patelli, Edoardo; and Au, Siu-Kui. Encyclopedia of Earthquake Engineering. Heidelberg: Springer Berlin Heidelberg.

Bhandari Bhakta, Roshan. 2014. Social capital in disaster risk management: A case study of social capital mobilization following the 1934 Kathmandu Valley earthquake in Nepal. Disaster Prevention and Management, vol. 23, 4: 314-328.

Cannon, Terry; Twigg, John; and Rowell, Jennifer. 2003. Social Vulnerability, Sustainable Livelihoods and Disaster. Report to DFID Conflict and Humanitarian Assistance Department, https://www. researchgate.net/publication/254398816_Social_Vulnerability_ Sustainable_Livelihoods_and_Disasters (consulted on 10/08/2020).

Cilliers, Juanne Elizelle; and Cilliers, Sarel. 2013. Planning for sustainable communities: Layout and design approaches. $49^{\text {th }}$ ISOCARP Congress: Frontiers of Planning - Evolving and declining models of city planning practice. The Hague: ISOCARP.

Clemente, Matteo; and Salvati, Luca. 2017. “Interrupted” Landscapes Post-Earthquake Reconstruction in between Urban Renewal and Social Identity of Local Communities. Sustainability, vol. 9, 11.

Clinton Jefferson, William. 2006. Lessons Learned from Tsunami Recovery: Key Propositions for Building Back Better. New York: Office of the UN Secretary-General's Special Envoy for Tsunami Recovery, https:// www.preventionweb.net/files/2054_VL108301.pdf (consulted on $15 / 08 / 2020)$

Dixit, Mani Amod; Parajuli, Krishna Yogeshwor; and Guragain, Ramesh. 2004. Indigenous skills and practices of earthquake resistant construction in Nepal. Proceedings of $13^{\text {rd }}$ World Conference on Earthquake Engineering. Vancouver: 13th World Conference on Earthquake Engineering Secretariat.

Environmental Camps for Conservation Awareness. 2016. Khokana Earthquake Debris Removal Initiative. Lalitpur, Bagmati: Environmental Camps for Conservation Awareness, https://www. globalgiving.org/pfil/21513/projdoc.pdf (consulted on 15/08/2020).

Gieryn, Thomas F. 2000. A Space for Place in Sociology. Annual Review of Sociology, 26: 463-496.

Government of Nepal. 1996. Khokana, the vernacular village and its mustard-oil seed industrial heritage. Katmandú: Department of Archaeology of the Ministry of Youth, Sports and Culture of the Government of Nepal, https://whc.unesco.org/en/tentativelists/844/ (consulted on $(07 / 08 / 2020)$

Hiller Bill, Hanson Julienne. 1989. Social Logic of Space. Cambridge: Cambridge University Press.

Hull R, Bruce. 1992. Image Congruity, Place Attachment and Community Design. Journal of Architectural and Planning Research, vol. 9, 3:.181-192.

ICCROM. 2000. Riga Charter on authenticity and historical reconstruction in relationship to cultural heritage. Riga: ICCROM, Latvian National Commission for UNESCO and State Inspection for Heritage Protection of Latvia, https://www.iccrom.org/sites/default/files/ publications/2020-05/convern8_07_rigacharter_ing.pdf (consulted on $12 / 08 / 2020)$.

ICOMOS. 1999. International Cultural Tourism Charter: Managing Tourism at Places of Heritage Significance. Mexico: ICOMOS, https://www.icomos.org/charters/tourism_e.pdf (consulted on 10/08/2020).

Karuppannan, Sadasivam; Kc, Chandani; and Sivam, Alpana. 2019. Importance of Cultural Heritage in Post-Disaster Setting. Journal of Social and Political Sciences, vol. 2, 2: 429-442. 
Khalaf W, Roha. 2017. A viewpoint on the reconstruction of destroyed UNESCO Cultural World Heritage Sites. International Journal of Heritage Studies, vol. 23, 3: 261-274.

Lawrence, L. Denise; and Low, M. Setha. 1990. The Built Environment and Spatial Form. Annu Rev Anthropol, vol. 19: 453-505.

Lekakis, Stelios; Shakya, Shobhit; and Kostakis, Vasilis. 2018. Bringing the Community Back: A Case Study of the Post-Earthquake Heritage Restoration in Kathmandu Valley. Sustainability, vol. 10, 8: 1-17.

National Planning Commission of Nepal. 2015. Post Disaster Needs Assessment, vol. B. Katmandú: National Planning Commission of Nepal, https://www.npc.gov.np/images/category/PDNA_volume BFinalVersion.pdf (consulted on 10/08/2020).

National Research Institute for Cultural Properties of Japan. 2016. Project for Investigation of Damage Situation of Cultural Heritage in Nepal. Tokyo: Japan Center for International Cooperation in Conservation, National Research Institute for Cultural Properties.

Nocca, Francesca. 2017. The Role of Cultural Heritage in Sustainable Development: Multidimensional Indicators as Decision-Making Tool. Sustainability, vol. 9, 10 .

Relph, Edward. 1976. Place and Placelessness. Thousand Oaks, California: SAGE Publishing Ltd.

Ruskin, John. 1849. The Seven Lamps of Architecture. Boston: Dana Estes \& Company.

Saruwono, Masran; Mohammad, Mastura Nik; and Said, Yani Shahrul. 2013. A Sense of Place within the Landscape in Cultural Settings. Procedia - Social and Behavioral Sciences, vol.105: 506-512.

Sharma, Keshab; Kc, Apil; Subedi, Mandip; and Pokharel, Bigul. 2018. Challenges for reconstruction after Mw 7.8 Gorkha earthquake: a study on a devastated area of Nepal. Geomatics, Natural Hazards and Risk, vol. 9, 1: 760-790.

Taylor, Ken; and Lennon, Lousie Jane. 2011. Cultural Landscapes: A bridge between culture and nature? International Journal of Heritage Studies, vol. 17, 6: 537-554

Ujang Norsidah, Zakariya Khalilah. 2014. The Notion of Place, Place Meaning, and Identity in Urban Regeneration. Procedia - Social and Behavioral Sciences, vol.170: 709-717.

Upadhyay, Anir; Yoshida, Harunori; and Rijal, Bahadur Hom. 2006 Climate Responsive Building Design in the Kathmandu Valley. Journal of Asian Architecture and Building Engineering, vol.5, 1: 169-176.

UNESCO. 2014. Education strategy 2014-2021. Paris: UNESCO, https://unesdoc.unesco.org/ark:/48223/pf0000231288 (consulted on $10 / 08 / 2020$ )

UNESCO; and The World Bank. 2018. Culture in City, Reconstruction and Recovery. Paris and Washington D.C.: UNESCO and The World Bank, http://documents1.worldbank.org/curated/ en/708271541534427317/pdf/131856-WP-REVISED-II-PUBLIC pdf onsulted on 20/08/2020).

UNISDR. 2017. Build back better in recovery, rehabilitation and reconstruction. Geneva: UNISDR, https://www.unisdr.org/ files/53213_bbb.pdf (consulted on 10/08/2020).

United Nations. 2008. Achieving Sustainable Development and Promoting Development Cooperation: Dialogues at the Economic and Social Council. New York: United Nations, https://www.un.org/en/ecosoc/docs/ pdfs/fina 08-45773.pdf (consulted on 09/08/2020).

\section{Biography $\mid$ Biografía $\mid$ Biografia}

\section{Komal Rokka}

She graduated from the School of Planning and Architecture, Bhopal, in August 2020. In 2019, she worked with a Nepal-based Architectural firm, Siddharth Gopalan Designs, as a design intern. During the course, she received guidance from the conservation specialist and Architect Rohit Ranjitkar in his Nepal Earthquake Response Campaign. Since then she has found herself inclined towards conservation and the social aspect of traditional architecture, while seeking ways to ensure its contemporary continuity.

\section{Sanjeev Singh}

$\mathrm{He}$ is a Professor in the Department of Architecture of the School of Planning and Architecture (SPA) of Bhopal and an Architecture graduate from the Government College of Architecture (now Faculty of Architecture of the Abdul Kalam Technical University, Uttar Pradesh). He holds a Master's degree in Environmental Studies from Melbourne University and a PhD from the National University of Singapore. His research interests are in the fields of Vernacular Architecture, Cultural Landscapes, and environmental studies. He has been running the Vernacular Studio at SPA Bhopal for the past nine years and his publications relate to his areas of interest. Currently he also holds the position of Dean of Planning and Development at SPA Bhopal. 